\title{
SATELLITE TRACKING DERIVED INSIGHTS INTO MIGRATION AND FORAGING STRATEGIES OF MALE LOGGERHEAD TURTLES IN THE EASTERN ATLANTIC
}

\author{
Varo-Cruz, N. ${ }^{a}$, Hawkes, L.A. ${ }^{\text {bc }}$, Cejudo, D. ${ }^{d}$, López, P. ${ }^{\text {, }}$ Coyne, M.S. ${ }^{f}$, Godley, B.J. ${ }^{\text {, }}$, López- \\ Jurado, L.F. ${ }^{a}$
}

\footnotetext{
a Dpto. de Biología, Universidad de Las Palmas de G.C. Campus de Tafira, 35017 Las Palmas de Gran Canaria, Gran Canaria, Spain b Centre for Ecology and Conservation, University of Exeter, Tremough Campus, Treliever Road, Penryn, Cornwall, TR10 9EZ, United Kingdom

c Bangor University, School of Biological Sciences, Bangor, Gwynedd, LL57 2UW, United Kingdom

d Cabo Verde Natura 2000, Sal-Rei, Boavista, Cape Verde

e Naturalia, Cape Verde Ltd., Sal-Rei, Boavista, Cape Verde

f Seaturtle.org 1 Southampton Place, Durham, NC 27705, United States
}

\begin{abstract}
In recent years, information about the movements and timing of migration by male sea turtles has begun to be unraveled. Here, we present the first satellite tracking of male loggerhead sea turtles (Caretta caretta) in the eastern Atlantic. Satellite linked transmitters were attached to five adult males, captured in the near shore waters off Boavista, Republic of Cape Verde. This archipelago hosts the single most important breeding site of loggerhead turtles in the eastern Atlantic. Animals were tracked for periods ranging between 48 and 537 days, including a probable annual remigration to the vicinity of the nesting ground for one turtle. Males showed a variety of movement patterns both during and after the breeding season. Of three males that transmitted for 85, 329 and 537. days, two (the smallest) migrated east and remained in oceanic waters for the tracking period and another (larger turtle) migrated 810. $\mathrm{km}$ northeast, to neritic waters off the coast of Mauritania, Western Africa. Results suggest males may show the same size-linked dichotomy in migratory strategies, as has been shown for females from this population.
\end{abstract}

